\title{
'Good Hunting': German Submarine Offensives and South African Countermeasures off the South African Coast during the Second World War, 1942-1945
}

\author{
Evert Kleynhans $\bullet$
}

\begin{abstract}
By the latter half of 1942, the High Command of the German U-boats (BdU) realised that the 'sinking results' of the North Atlantic had decreased immensely. The successes of the Allied anti-submarine operations in the North Atlantic precluded the successful employment of the German submarines in said waters. It was realised that the 'sinking potential' of the Cape Town-Freetown convoy route, in terms of tonnage, had increased exponentially by the latter half of 1942 . This sudden increase was a direct result of the successful German submarine operations in the North Atlantic during 1939-1942. The first German submarine offensive in South African waters during 1942, Operation Eisbär, was aimed at striking a devastating blow to shipping off the South African coast. By the end of December 1942, an estimated 310864 tons of shipping had been sunk through Operation Eisbär and the first Ucruiser operation alone. The success of Operation Eisbär led to a further two German submarine offensives being launched by the BdU in South African waters during the remainder of the Second World War, with a number of opportunistic attacks also made by submarines travelling to the Far East. This article has three specific aims. First, to discuss the Union Defence Force's (UDF) threat perception and operational readiness in terms of the maritime defence of its coast, and the merchant shipping that rounded it, over the period September 1939 to October 1942. Second, to explain the nature and extent of the German submarine operations in South African waters ${ }^{1}$ between October 1942 and February 1945. Last, the South African and Allied counter-measures to the German submarine threat off the South African coast will be discussed. By drawing from a myriad of primary archival sources, private and official correspondence, and a host of secondary sources, the background, nature, successes and failures of the German submarine operations, and the South African counter-measures are elucidated.
\end{abstract}

Keywords: UDF, Operation Eisbär, Seehund, Wicketkeeper, anti-submarine warfare

\section{Introduction}

During 1935, Adolf Hitler, who had risen to power in Germany during 1933, appointed Karl Dönitz as the commander of the interwar Reichsmarine's (German Navy) resurrected U-boat arm. Whilst rebuilding the U-boat arm to be a viable threat to merchant shipping in the near future, Dönitz advocated the construction of large fleet of medium-sized U-boats that could perfect his notion of Rudeltaktik. In principal, Dönitz's Rudeltaktik, or pack tactics, concluded that a large body of U-boats,

Evert Kleynhans, MMil (Stell), is a doctoral candidate in the Department of Military History, Stellenbosch University (SU). His thesis focusses on the Axis and Allied maritime operations in the southern oceans during the Second World War. Other research interests include the South African participation in both world wars, the impact of weather and terrain on warfare in Africa, and the wider milieu of war and society in southern Africa. He can be contacted at evertkleyn@gmail.com. 
acting in unison, could successfully concentrate and ensure the destruction of a merchant convoy. ${ }^{2}$ During the early stages of the Second World War, declared on 3 September 1939, Britain had approximately 3000 merchantmen at her disposal, which had to ensure the island nation's survival by hauling key logistical needs from across the British Empire over vast, often unprotected, sea lanes. By ensuring that the sinking of Allied merchantmen outnumbered the capacity to replace them, Dönitz could cripple the Allied war effort by simply controlling the oceans. Dönitz was, however, soon to realise that his theoretical calculations were often hard to achieve in practice. ${ }^{3}$ The German submarine campaign, initially a limited one aimed at primarily attacking the merchant fleets of Britain and her Allies, brought about the adoption of a convoy system in order to safeguard merchant shipping. Dönitz calculated that if the British established convoys, then U-boats would be able to attack merchants without warning according to the German interpretation of the London Submarine Agreement of $1936 .{ }^{4}$

The German occupation of France in May 1940 provided the BdU with an opportunity to relocate their submarine bases from Wilhelmshaven on the Baltic Coast, to the relative safety of the Bay of Biscay. These U-boat bases directly threatened the Allied convoy routes to and from Britain by ensuring that the U-boats did not have to traverse the northern approaches of Scotland in order to avoid the Allied minefields in the Strait of Dover. ${ }^{5}$ By the end of 1941, Dönitz's U-boats had managed to reduce British imports from 55 million tons in 1939, to a mere 35 million tons. By operating as far afield as the coasts of the Mediterranean, Brazil and West Africa, the U-boats were on the brink of sinking Allied merchant shipping faster than it could be replaced. ${ }^{6}$ The year 1942, the height of the Battle of the Atlantic, proved only a partial success for the U-boats operating in the North Atlantic Ocean. The Allied response to the growing U-boat threat had improved considerably by the latter half of 1942, through the increasing skill of convoy and escort commanders, the ready availability of reliable submarine detection equipment ( $\left.\operatorname{ssdic}^{7}\right)$, and the great improvement of antisubmarine weapons. The Allied ability to read German naval ciphers, after breaking the everchanging German naval codes by mid- $1941,{ }^{8}$ coupled with a greater number of escorts and a diminishing 'air gap' in the North Atlantic, furthermore curtailed Dönitz's successful employment of his wolf packs. The Allies had started to turn the tide of the Battle of the Atlantic in their favour. ${ }^{9}$

During the spring of 1941, the BdU had already appreciated the fact that the Cape TownFreetown convoy route would make an excellent target for a concentrated U-boat offensive. The port of Freetown, in Sierra Leone, served as an assembly point for all merchant shipping going to and coming from Europe, the Middle East and the Far East. This convoy route passed along the strategic maritime nodal point of the Cape of Good Hope, which ensured that all ships, which passed along this route, had to stop over at either one of the key South African ports of Saldanha, Cape Town, East London, Port Elizabeth or Durban. At Freetown, the slower merchantmen formed into convoys for their onwards journey, whilst the faster ships sailed independently. The BdU, appreciating the logistical problems associated with operations in the central and southern Atlantic, experimented with the use of the supply U-boats (milch cows ${ }^{10}$ ) during 1941. The operational U-boats in the central and southern Atlantic could hence remain at sea for twice the time that it could before owing to the several rendezvous points with supply ships or U-boats, which were established across the Atlantic Ocean. By the end of October 1941, however, the BdU temporarily withdrew all U-boats from the West Coast of Africa due to a considerable reduction in British shipping, which had denied the area of sinking potential necessary to a sustain a submarine offensive. ${ }^{11}$ By February 1942, the B-Dienst ${ }^{12}$ reported that there was a definite increase in British transatlantic shipping off the coast of Freetown. The ineffectiveness of the Pan-American safety zone, defunct after the American entry into the war in December 1941, ensured that merchant shipping had to use the route along the West Coast of Africa and around the Cape of Good Hope. ${ }^{13}$ 
By the latter half of 1942, the BdU had reached the conclusion that the sinking results of the Uboats operating in the north Atlantic had decreased to such an extent, due to effective Allied antisubmarine warfare, that an operation off the coast of Southern Africa proved viable. By ordering his wolf packs south, Dönitz had hoped to cause a diversionary effect whereby the Allies would be forced to split their defensive forces between protecting the North Atlantic, the Eastern American seaboard and the extensive African coast. This would cause the Allies to intensify the use of the convoy system, and to use the longer sea routes around the Cape of Good Hope, which were more prone to attacks by U-boats. ${ }^{14}$

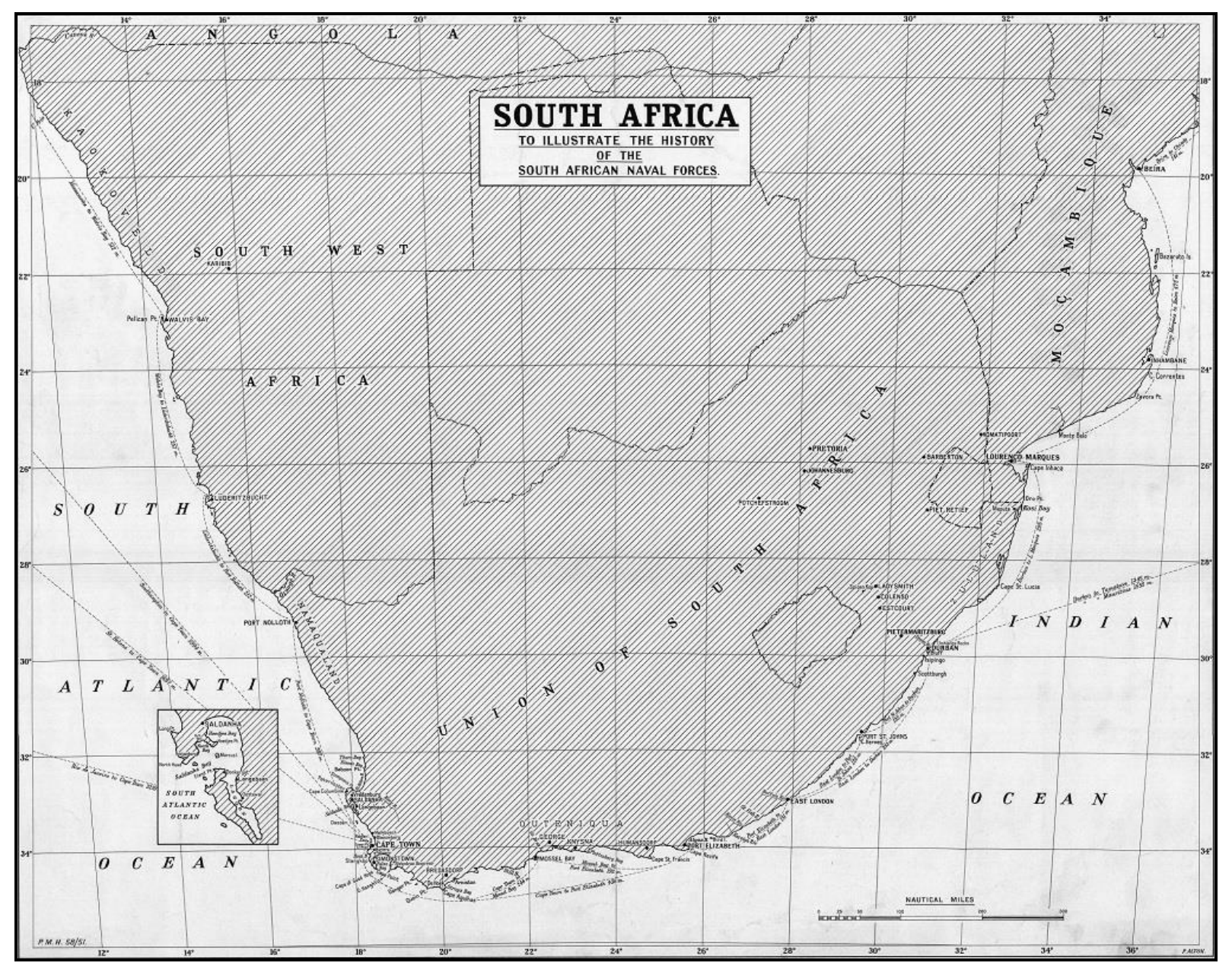

Map 1: The South African coastline 1939-1945 ${ }^{15}$

During the latter half of 1942, the waters off Cape Town, considered 'virgin' waters by the BdU, were devoid of any substantial submarine activity. Prior to 1942, there were, however, some instances when single U-boats ventured as far south as Cape Town and attacked shipping. During October/November 1941, U-68 had managed to sink both the Hazelside and Bradford City off the coast of South-West Africa. The BdU did, however, not favour sending single U-boats to operate off the southern African coast, for their independent actions would alert the Allies and force them to adopt stringent anti-submarine measures. Moreover, a single submarine operating off Cape Town would not reach sufficient sinking results needed to justify its deployment. The BdU realised that an operation off Cape Town could only materialise once sufficient numbers of U-boats were available to launch a concentrated attack and sustain it for an indefinite period to allow for sufficient sinking 
results. Dönitz argued that the primary focus of a war of tonnage was the sinking of Allied merchant shipping, not the tying down of enemy forces and diversionary attacks. ${ }^{16}$ By the latter half of 1942, the Allies concentrated the majority of its escort fleets to protect the North African and Mediterranean waters due to the campaign in North Africa, enticing Dönitz to strike towards the proverbial 'soft underbelly' of South Africa. ${ }^{17}$

\section{The South African maritime threat perception, September 1939 to October 1942}

The South African declaration of war on Germany on 6 September 1939 ensured that the Union had to ensure the safe passage of all friendly shipping travelling along the Southern African coast and safeguard those which visited her ports. The South African coastline then stretched from the mouth of the Kunene River on the Atlantic Ocean to Kosi Bay on the Indian Ocean, and included the critical coastal juncture of the Cape of Good Hope. All merchants ships which travelled along the South African coast during the war, called at one or more of the following ports: Walvis Bay, Saldanha Bay, Cape Town, Port Elizabeth, East London and Durban. ${ }^{18}$ The continuous operation of the maritime trade route around the South African coast ensured that critical war supplies from across the British Commonwealth, and most importantly, India, could travel to and from Britain. During the early years of the war, especially with the Allied campaigns in East Africa and North Africa, the South African ports furthermore acted as vital logistical ports of call for all Allied troopships rounding the Cape of Good Hope whilst transporting soldiers between the operational theatres. The Allied war effort was thus reliant on the safe passage of the merchant shipping around the Cape of Good Hope, and their defence and continued operation were thus not only a South African problem, but due to their vital importance, also a combined Allied one. ${ }^{19}$

The defence of South Africa's maritime trade routes fell into two broad categories. In order to ensure the maintenance of sea communications around the South African coast, the South African threat perception and counter-measures thus had to take into account the differing maritime threats prevalent in the Atlantic and Indian Oceans. The maritime threat off South Africa's Atlantic coast was confined to the threat of German submarines and surface raiders when operating as far south as the South Atlantic Ocean. It was estimated by British Naval Intelligence that a German U-boat offensive around the South African coast would be limited, never exceeding more than six submarines at a time, owing to the vast operational distances to be covered by the U-boats whilst en route to the Cape Town waters. It was further known that German surface raiders were operational in the South Atlantic, and that these held a definite threat to merchant shipping in those waters. The combined threat of the German surface raiders and U-boats was heightened by the fact that both were known to have the ability to mine vital junctures around the South African coast, which included Saldanha, Cape Town, Port Elizabeth, East London and Durban. ${ }^{20}$ The maritime threat along South Africa's Indian Ocean coastline was confined to that of Japanese submarines and surface raiders operational in this area. ${ }^{21}$ The Japanese submarines, despite their nearest base being 5000 miles away, were known to be operational as far south as the Mozambique Channel, and thus could threaten the merchant traffic off the entire South African eastern seaboard when provisioned from the Vichy French at Madagascar and possible subversive elements in Portuguese East Africa. The presence of Japanese surface raiders, some known to be carrying midget submarines, were also anticipated, and their numbers were believed to be bolstered by a number of German submarines and surface raiders during certain times. The presence of Japanese and German warships in the Southern Atlantic and Indian Oceans was considered, but thought of as unlikely. ${ }^{22}$

Despite the views held by British Naval Intelligence, the UDF, and more notably the Chief of the General Staff (CGS), Lt Gen. Sir Pierre van Ryneveld, anticipated that the primary threat to the 
maritime trade routes around South Africa's coast would emanate from Japanese and Italian submarines operational in the Indian Ocean. The German threat was considered, but was not seen as viable owing to the illusion that the vast operational distances from the Bay of Biscay would prevent their successful employment in the Indian Ocean. ${ }^{23}$ It was realised that the main aim of the Axis operations in South African waters was to sever the Allied sea route around the Cape of Good Hope to the Middle East, India and the Far East. The majority of maritime attacks were consequently expected in the areas where the sea traffic would be most concentrated - Durban, Port Elizabeth and Cape Town. The closest maritime threat to South Africa in 1940 was the Italian submarines known to be based in the Red Sea port of Massawa, a mere 3800 miles from the strategic port of Durban. In an UDF intelligence summary of 1940, it was estimated that the Italian submarines stationed at Massawa held a definite threat to South African merchant shipping. It was realised that, if the Italian submarines could use Kismayu in Italian Somaliland as a forward operational base, and in some instances even be replenished from Portuguese East Africa, Allied shipping as far south as Cape Town and its roadstead could be directly threatened. The Italian submarine threat along South Africa's eastern seaboard, however, never materialised, due to the successful Allied campaign fought in East Africa, which eliminated the Italian naval threat in the Red Sea and Indian Ocean by $1941 .{ }^{24}$

By the end of December 1941, the chief of staff of the Seekriegsleitung ${ }^{25}$ (SKL), Vice Admiral (VAdm) K Fricke, met with the Japanese naval attaché in Berlin, VAdm N Nomura, to discuss the respective Japanese and German submarine operational areas across the globe. By March 1942, Fricke and Nomura met once more. This time round, however, the strategic importance of the Indian Ocean and the Allied maritime trade routes across it was discussed, and on 8 April, Nomura accepted Fricke's proposal that a Japanese submarine offensive be launched in the Indian Ocean. The Japanese Navy subsequently committed between four and five submarines and two auxiliary cruisers for offensive operations in the Indian Ocean between the Gulf of Aden and the Cape of Good Hope. ${ }^{26}$ Between 5 June and 8 July 1942, after the commencement of the Allied invasion of Madagascar, Operation Ironclad, the Japanese submarines managed to sink 19 Allied merchants off the coast of Mozambique, amounting to a staggering 86571 merchant tons lost within the space of a month. The southernmost sinking of this limited Japanese submarine offensive occurred a mere 95 miles northeast of Durban, when the British merchant Mundra was sunk on 6 July 1942. By convincing the Japanese to launch a submarine offensive in the Indian Ocean by mid-1942, with emphasis on operations around the Seychelles, Ceylon (Sri Lanka) and Madagascar, Dönitz had in fact created the diversionary effect that he had hoped for. The Allied attention was now split between the campaigns in North Africa, the invasion of Madagascar, and the protection of shipping off the West African and American seaboards, which ensured that an attack around the coast off Cape Town would not be expected. Owing to the encroaching Japanese threat to South African sovereignty and Allied shipping off the country's eastern seaboard during 1942, Van Ryneveld and his staff were forced to prepare for any eventuality, even that of a full-scale Japanese invasion. All attention was thus directed towards early warning and anti-submarine warfare along South Africa's east coast. ${ }^{27}$

By 1942, the South African coastal defences were divided into six different fortress commands, which each covered an operational sector based upon its geographical locality. As such, there was the Cape, Durban, Port Elizabeth, East London, Outeniqua and Walvis Bay fortress commands, which all resorted under the auspices of a Central Coastal Command based in Cape Town. ${ }^{28}$ By April 1942, the general policy decided upon for the defence of South African ports and the country's extensive coastline, was the ability, and indeed mobility, of the UDF, the South African Air Force (SAAF), and the Royal Navy (RN) to concentrate sufficient forces at a moment's notice where a threat existed. It was furthermore argued that, in order to ensure the safety of merchant shipping around its coast, the UDF would have to prioritise the defence schemes of its ports in order to expel any form of Axis 
attack effectively. Of the seven vital South African ports, only Cape Town, Simons Town and Durban had antisubmarine defences worth mentioning, with only Cape Town, Durban and Port Elizabeth having support from SAAF squadrons..$^{29}$ The remainder of the South African ports' defence schemes was still in a planning phase by February 1942. ${ }^{30}$

Because the Axis threat to Allied shipping around the South African coast had not materialised by mid-1942, a lacklustre attitude was prevalent in terms of coastal defence. This was highlighted by the fact that the South African Railways and Harbours was only asked to switch off non-essential harbour and coastal lights during June 1942, after the commencement of the Japanese submarine offensive off the east coast of South Africa. ${ }^{31}$ By 4 October 1942, a mere four days before the first German submarine offensive would be launched in the waters off Cape Town, an RN intelligence appreciation from the Commander -in-Chief (C-in-C) South Atlantic, VAdm WEC Tait, failed to report the presence of a body of German submarines moving south towards Cape Town. Despite various naval intelligence sources indicating the southward movement of a number of U-boats, coupled with the Laconia ${ }^{32}$ incident of a few days before, it would seem as if Tait and his staff had also been lulled into a false sense of security. All attention was indeed focused on the Indian Ocean and the presumed Japanese threat. Whilst Tait's circular, No. 047/28, explicitly stated that the "Naval object is the safety of Merchant Shipping", focusing specifically on Cape Town, Tait suggested that he had an insufficient number of naval forces to even consider an offensive operation, and that "it is probable that the first news of the presence of enemy raiders, whether surface or submarine, in the area will be the report of their first attack". ${ }^{33}$

\section{The U-boat offensives off the South African coast}

By August 1942, the BdU had a large number of the type IXc U-boats to its disposal, which exponentially increased the duration of U-boat operations. These new U-boats, acting in conjunction with the milch cows, meant that the offensive employment of the German submarines was now extended to areas previously devoid of any sustained U-boat operations. It was decided that four Uboats ( $U-68$ [Merten], $U-172$ [Emmermann], $U-504$ [Poske] and $U-156$ [Hartenstein]) would form the initial core of the German wolf pack, which was designated to strike the crucial blow at shipping in the waters off Cape Town. The subsequent U-boat operation, Operation Eisbär, was aimed at the disruption and destruction of merchant shipping around the Cape of Good Hope during October 1942. Dönitz argued that the submarines were to remain in the operational area off Cape Town until approximately the end of October, in order to achieve the necessary sinking results required to make this far-flung operation a success, after which the wolf pack would be relieved by a fresh batch of Uboats. ${ }^{34}$

The Eisbär boats sailed for Cape Town from their base at Lorient in France by 20 August, whilst the milch cow designated to the operation, $U-459$ (Wilamowitz), departed from Bordeaux at the same time. The U-boats had to cover approximately 6000 sea miles before they reached the operational waters off Cape Town. The SKL required the U-boats to remain undetected for their entire voyage to Cape Town in order to ensure that the surprise factor was maintained. ${ }^{35}$ The SKL argued throughout the month preceding the launch of Operation Eisbär that the most important factor to consider was the strategic effect which the operation would achieve, namely that of throwing the traffic off the coast of South Africa into such a state of confusion that sea traffic around the Cape of Good Hope would be brought to a halt, whilst her ports became clogged with the ever-increasing numbers of merchant shipping seeking shelter. This strategic effect could only be achieved through surprise. The BdU and Dönitz, however, argued that the most important factor to consider during the entire operation would be the actual sinking results, which could be achieved by the Eisbär boats. 
Dönitz thus argued that Eisbär boats should be allowed to attack shipping during their entire approach voyage to Cape Town. The ultimate goal of the operation, Dönitz argued, was a short, sharp, submarine offensive, which could yield the highest possible sinking results in the shortest possible time without incurring too many submarine losses. The SKL and BdU reached a compromise, for it was decided that the U-boats were allowed to carry out attacks on merchant shipping during their approach voyage to Cape Town, but that these attacks were confined to the area between the equator and $5^{\circ}$ south. ${ }^{36}$ During this melancholic debacle, Dönitz was quoted as saying, "The strategists are again out to tickle the enemy. Unfortunately I do not know of a single case, when an enemy had been tickled to death." ${ }^{37}$

During their voyage south, the Eisbär boats attempted for some time, albeit unsuccessfully, to attack a convoy, which was making its way to Freetown. Whilst each U-boat continued its journey further south independently, the wolf pack travelled in an extended harrow bone formation spread out across a vast distance so as to remain undetected. The U-boats were ordered to replenish their supplies from $U-459$ on 20 September at a position approximately $20^{\circ}$ south of the equator. ${ }^{38}$ Whilst en route to rendezvous with $U-459, U-156$ sank the British troopship Laconia on 12 September. ${ }^{39}$ This article does, however, not deal with the sinking of the Laconia, but it is of interest to note that the remainder of the Eisbär boats were ordered by the BdU to assist in the rescue operation of the survivors. The Uboats were only dismissed from the rescue operation once it had become known that two French colonial boats had been despatched to help with the rescue. On 16 September, $U-156$ was severely damaged by an indiscriminate Allied bombing attack, and the BdU was forced to recall the U-boat from Operation Eisbär. The BdU immediately replaced $U-156$ with $U-159$ (Witte) on 15 September, because the latter was in the equatorial area making its way to an operational area off the mouth of the Congo River. Between 22 and 24 September, after having been withdrawn from the rescue operation of the Laconia, the Eisbär boats rendezvoused with $U-459$ to the south of the Atlantic island of St Helena where the U-boats successfully replenished their logistical supplies. The new supplies enabled the submarines to continue their operational voyage for a further 30 days. The remainder of the Uboats' journey south occurred without incident, and the Eisbär boats arrived off the coast of Cape Town during the first week of October $1942 .{ }^{40}$

On the night of 6/7 October 1942, U-172 (Emmermann) managed to infiltrate his U-boat successfully into Cape Town harbour's roadstead, and after conducting a reconnaissance found it to be empty of Allied merchant shipping. The BdU had decided that the attacks of Operation Eisbär would commence on the night of 8/9 October, but after Emmermann's report, it was decided that the attack would only commence on the night of 10/11 October. During the same night, however, U-68 (Merten) was steadily approaching Cape Town, after having trailed several steamers on their approach to the Cape Town harbour, when Emmermann's report was received stating that the roadstead was empty. The BdU was immediately informed by Merten of the changing tactical situation in the waters off Cape Town harbour, after which the BdU granted authority for the submarine attacks to commence at midnight on 8 October. ${ }^{41}$ When the Eisbär boats launched their attack on the night of 8 October, it seemed to the U-boat commanders that the South African defences were caught totally unaware. It seemed to Witte and the BdU as if the wireless transmissions of neither $U-172$ nor $U-68$ were intercepted by the Cape fortress command, for their presence remained undetected. ${ }^{42}$

The resulting U-boat offensive succeeded in sinking 14 ships within three days from the commencement of the offensive operations, with $U-179$ (Sobe) and $U-178$ (Ibbeken) also arriving to support Operation Eisbär. Whilst the surprise gained during the initial attack started to dwindle, and the South African and Allied counter-measures and anti-submarine operations were activated, Dönitz ordered his U-boats to extend their operational areas to as far afield as Port Elizabeth and Durban. The 
initial attacks on the merchant shipping off Cape Town was made easy by the fact that the majority of South African lighthouses were still functioning at full capacity, whilst most merchants sailed independently around the South African coast. Because of this lacklustre attitude present in South Africa, very few anti-submarine vessels and aircraft were operational in this area. The U-boat pickings were thus easy. Bad weather arrived by 13 October, which forced the submarines further afield, with $U-159$ even venturing as far as $40^{\circ}$ south in search of merchant vessels. ${ }^{43}$

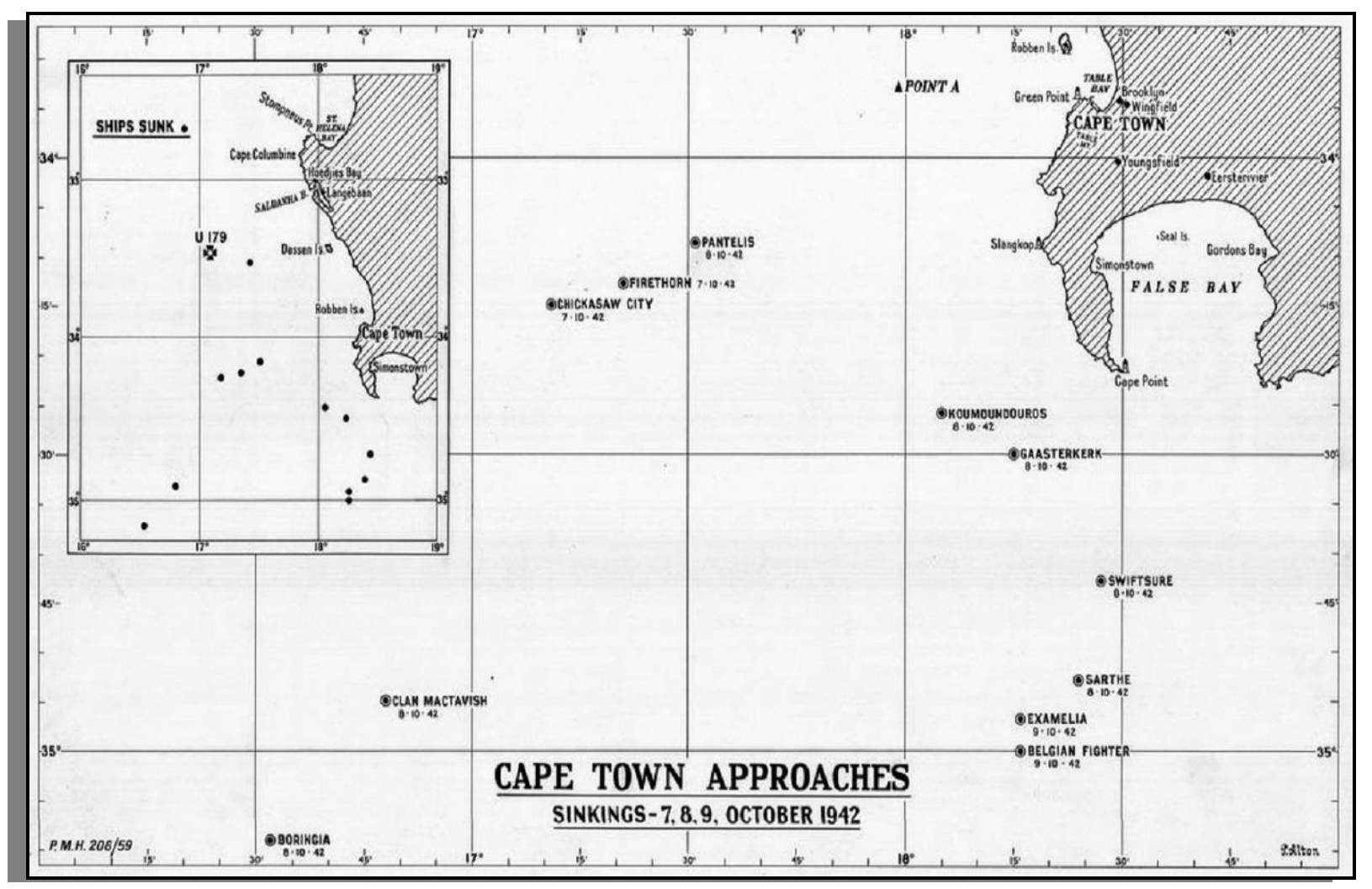

Map 2: Operation Eisbär - The initial attacks off Cape Town ${ }^{44}$

The arrival of $U 179$ and $U-178$ was greatly anticipated by the Eisbär boats, for Emmermann and his colleagues realised that with greater numbers, they would be able to operate across a wider area and possibly sink a greater number of merchant shipping off the South African coast. The BdU decided that $U-504$ and $U-159$ would move further south and south-east of Cape Town, after which they managed to succeed in sinking a few targets. Shortly after the commencement of Operation Eisbär, $U-68$ and $U-172$ were forced to commence their return voyage even before they had managed to fire all of their torpedoes. ${ }^{45}$ These two U-boats were, however, able to sink six enemy merchant ships apiece, with $U-68$ sinking 36385 and $U-172$ sinking 47807 merchant tons respectively. It was initially expected that $U-179$ would arrive off Cape Town on approximately 13 October, but Sobe sailed at great speed from the equator in order to arrive off Cape Town for the commencement of the Eisbär offensive on 8 October. The fate of $U-179$ was, however, sealed, for shortly after Sobe had arrived off Cape Town, his U-boat was sunk on 8 October by the depth charges of HMS Active. The sinking of $U-179$ was the only operational loss of a U-boat during the entire span of Operation Eisbär. For the remainder of the Second World War, the BdU believed that $U-179$ had been sunk by Allied bombers off the coast of Ascension Island, whilst on her return voyage to Lorient. ${ }^{46}$ 
During the remainder of October and the beginning of November, $U-181$ (Lüth) and $U-177$ (Gysae) also arrived off the coast of Cape Town. The two U-boats, in conjunction with $U-178$, were ordered to operate off the coast of Lourenço Marques and further south towards Durban, and collectively they formed part of the first U-cruiser operation in the South Atlantic. The three U-boats were extremely successful during their operation, for they managed to sink 23 merchant ships, including the British Auxiliary Cruiser Nova Scotia, which had 800 Italian civilian internees on board. Fearing a repeat of the Laconia incident, the BdU ordered the U-boats not to attempt a rescue operation. ${ }^{47}$ By mid-November, the SKL ordered all remaining German submarines off the South African coast to return to the North Atlantic and the Mediterranean, in order to attack Allied shipping after the successful American landings in North Africa during Operation Torch. The BdU, however, proved to the SKL that operations as far south as the waters off the South African coast were indeed possible and that those could yield good sinking results. During the period 8 October-2 December, eight U-boats had managed to sink 53 Allied merchant ships, for the loss of only one U-boat. In essence, the sinking results were thus an average of 6,25 merchant ships sunk per operational U-boat, with a grand total of 310864 tons of merchant shipping lost off the coast of South Africa between October and December 1942. ${ }^{48}$

During December, once the American landings in North Africa had been successful, the SKL once more requested the BdU to send U-boats to Cape Town with the hope of further successes like those achieved during the latter half of 1942. The BdU decided that the new operation would focus on disrupting the Allied merchant shipping from the United States of America round Cape Town to Russia. There were, however, not enough long-range U-boats available until the spring of 1943 to execute this operation. The BdU subsequently decided that $U-506, U-516, U-509$ and $U-160$ would form the core of Operation Seehund, the new German submarine offensive destined for the South African waters. The U-boats departed from their bases in the Bay of Biscay during December 1942 and January 1943, after which they replenished their supplies from $U-459$ at approximately the same position as that of the Eisbär boats. ${ }^{49}$ The Seehund boats travelled further south towards Cape Town without any noteworthy incidents taking place, after which the U-boats arrived in the operational area off Cape Town during February 1943. The sinking results of Operation Seehund were, however, negligible for the entire time during which the U-boats were operational off the coast of South Africa. The operational conditions in the South Atlantic, and more notably off the coast of South Africa, had indeed changed drastically since October 1942. The UDF, and the Allies for that matter, had adopted a number of defensive anti-submarine measures, which were aimed at curtailing the losses of merchant ships around the South African coast. ${ }^{50}$

By the beginning of March 1943, the Seehund boats were ordered to proceed towards Durban where it was believed that the merchant pickings were better. The initial operational period of the Uboats off the coast between Cape Town and Port Elizabeth yielded but a few results, with only six merchant ships, amounting to a total of 36650 tons, sunk between three U-boats (U-506,U-509 and $U$-516). Having moved further eastward to operate off the coast of Durban, and the southern extremities of the Mozambique Channel, $U$-160 managed to sink six merchant ships between 3 and 11 March, amounting to a total of 38014 merchant tons. ${ }^{51}$ None of the other U-boats managed to sink a single ship off the coast of Durban, and by the latter half of March, the Seehund boats were ordered back to the operational area between Cape Town and Port Nolloth. By the end of March, the Seehund boats were ordered to the vicinity of Walvis Bay, where $U-509$ and $U-516$ managed to sink a further two merchant ships. Operation Seehund had indeed not been as successful as the SKL had hoped, for between 10 February and 2 April 1943, the six U-boats had only managed to sink a total of 14 merchant ships, a mere 85456 tons of merchant shipping. The BdU realised that the operational 
results of Operation Seehund had indeed been disastrous despite no U-boat being lost during the operation. $^{52}$

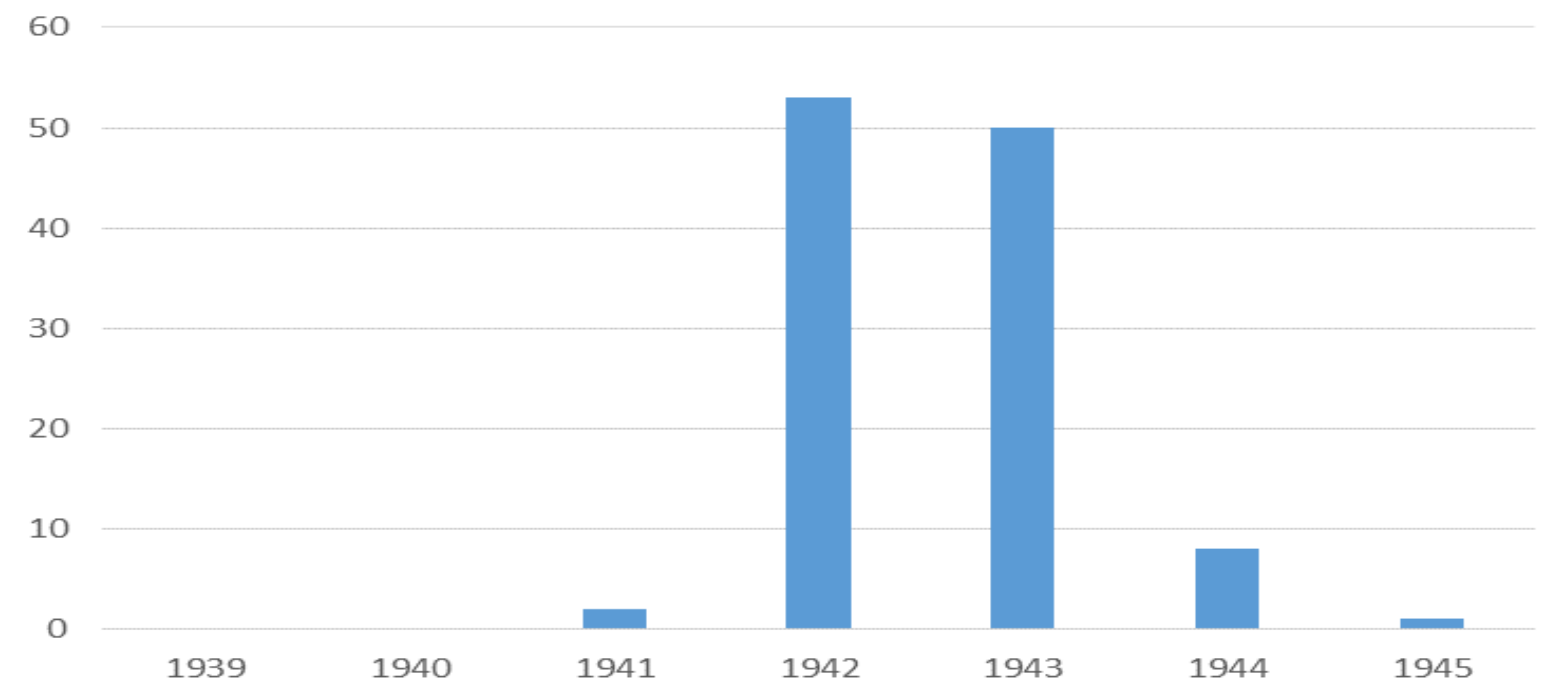

Graph 1: Merchant losses to German U-boats off the South African coast 1939-1945 $5^{53}$

By April 1943, only $U-182$ remained operational off the South African coast. Having arrived during the latter half of February, $U-182$ could by 5 April only account for three merchant ships sunk. By mid-April, $U-182$ was joined by $U-180$, which was en route to Madagascar, where it was supposed to rendezvous with a Japanese submarine and deliver the Indian dissident Chandra Bose. After the successful delivery of Bose, $U-180$ remained in the operational area off the South African coast and only managed to sink one merchant, the British merchant Corbis, on 18 April. During May, a number of sinking successes were achieved between Cape Town and the Mozambique Channel. In addition to $U-180$, a number of U-boats ( $U-177, U-181, U-178, U-197$ and $U-198)$ had arrived off the coast of South Africa during the latter half of April, and collectively formed part of the second U-cruiser operation in the South Atlantic. The sinking results amounted to seven merchant sunk during May alone. The main reason behind the sudden successes appears to have been the greater speed which could be reached by the type IXD2 U-boats. This was partially the result of a larger supply of fuel on board, which subsequently allowed the U-boats to operate in a far larger area off the coast of South Africa, exponentially increasing the submarine's potential for success in those waters. ${ }^{54}$ By the end of June, the U-boats replenished their stores from a German surface tanker, the Schliemann, 100 miles to the south of the island of Mauritius. After the replenishment, the six U-boats were ordered to new operational areas, which saw the submarines operating towards the east coast of South Africa in a quadrant between Durban, Lourenço Marques, the Mozambique Channel, Mauritius and Madagascar. During this operation, $U-197$ was lost on 20 August after being bombed by Allied aircraft just south of Madagascar. These boats accounted for 26 merchant ships sunk between May and August, with a total of 145568 tons of Allied merchant shipping lost. Despite more effective South African and Allied counter-measures, Dönitz's U-boats had still managed to sink 50 merchant ships, a total of 297076 tons, during the whole of 1943 off the coast of South Africa. ${ }^{55}$ 


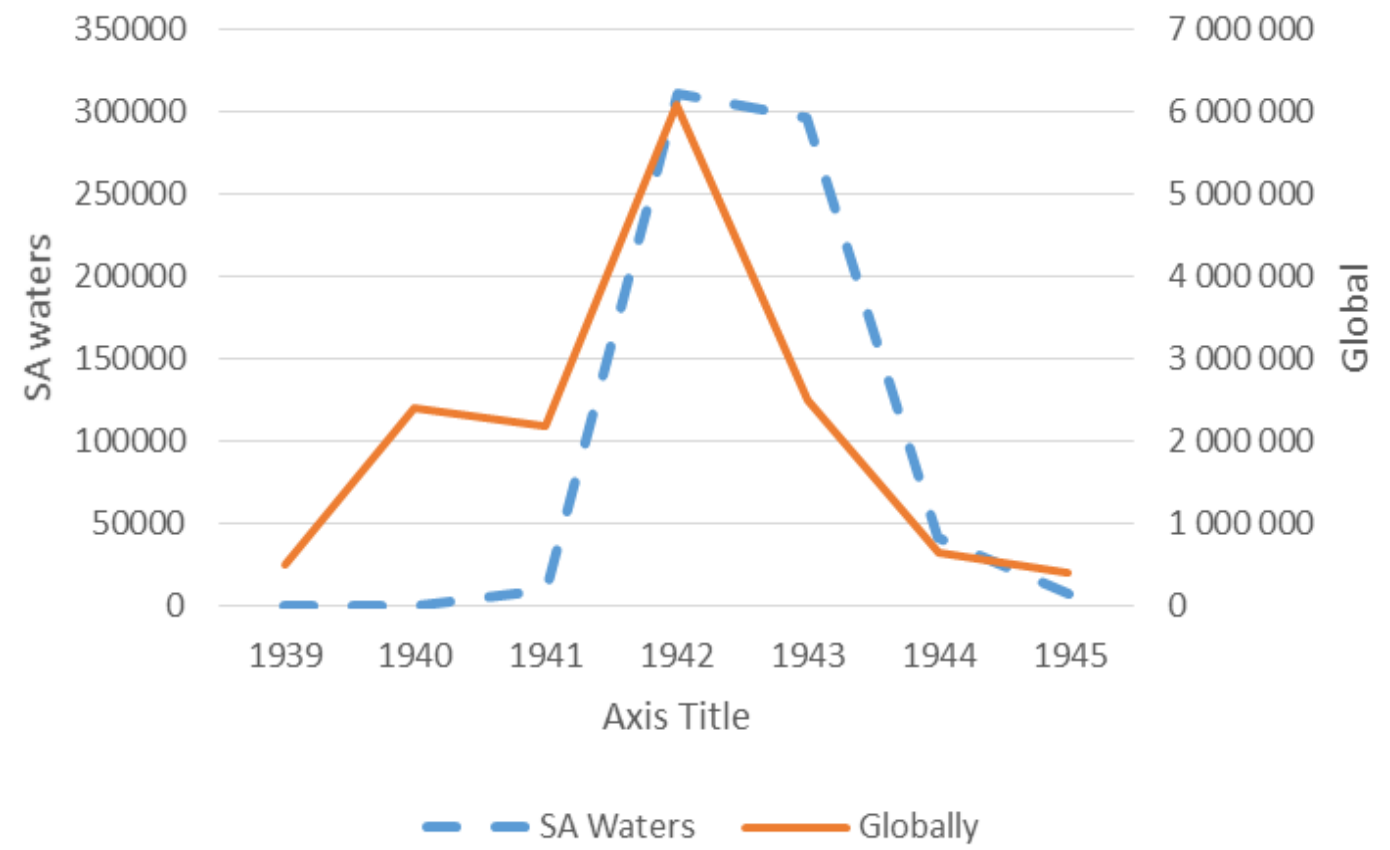

Graph 2: Comparison of merchant tonnage lost in South African waters to that globally, 1939-1945 56

During the remainder of the Second World War, more notably from September 1943, the area off the South African coast ceased to be regarded as a viable operational area by Dönitz. The BdU argued that the submarines earmarked for offensive operations in the Far East would have to pass through South African waters before they could reach their far-eastern bases at Penang and Surabaya. This would provide the U-boats with ample opportunity to attack Allied merchant shipping off the South African coastline during their journey to the east. ${ }^{57}$ The anti-submarine measures had become so efficient around the South African coast - especially the well-organised air patrol service by the South African Air Force (SAAF) and the Royal Air Force (RAF) - that the U-boats found it increasingly difficult to operate successfully against merchant shipping. There were, however, exceptions to the rule. During 1944, four U-boats (U-862 [Timm], U-852 [Eck], U-198 [Waldegg] and $U-861$ [Oesten]) managed to sink eight Allied merchant ships, accounting for 42267 merchant tons lost. During 1945, a last Allied merchant ship was sunk off the coast of South Africa, when the Point Pleasant was sunk by $U-510$ on 23 February. ${ }^{58}$

The German submarines effectively operated off the South African coast from 1941 to 1945, with the main U-boat operations occurring between October 1942 and August 1943. The German Uboats operating off the coast of South Africa during the Second World War could account for 114 Allied merchant ships sunk, with an accumulated gross total of 667593 merchant tons lost. In total, the merchant tonnage lost to U-boats throughout the Second World War accumulated to 14915921 gross merchant tons. The gross merchant tonnage lost off the South African coast to German submarines, only accounted for a mere $4.5 \%$ of the total merchant tonnage lost to U-boats throughout the Second World War. Throughout the War, the total merchant tonnage lost in South African waters to all forms of Axis activity, which included sea mines, surface raiders and submarines, amounted to 885818 gross merchant tons lost. Of this figure, the successive U-boat offensives accounted for $75 \%$ of the total sinkings in said waters. When isolated to South African figures alone, the percentages 
seem impressive. When juxtaposed against total merchant losses throughout the Second World War to U-boats, however, the figures are less convincing. ${ }^{59}$

\section{South African and Allied counter-measures}

In order to gauge the effectiveness of anti-submarine warfare in South Africa waters, it is necessary to make a comparison between the measures that were in place before the commencement of Operation Eisbär, and those prevalent by the end of the main U-boat offensives off the South African coast in 1944. Prior to the commencement of the first sustained U-boat offensive off the South Africa in October 1942, anti-submarine warfare in these waters were rather haphazard and curtailed by a number of factors.$^{60}$ First, there was insufficient warning of the impeding German submarine attack, despite intelligence summaries noting the presence of a large body of U-boats steadily making their way into the South Atlantic throughout the preceding weeks. The provision of accurate intelligence was thus the most pressing issue that had to be addressed, for without accurate intelligence it proved immensely difficult to determine the commencement of any German submarine movements around the coast of South Africa. ${ }^{61}$ Second, the number of naval escorts available in the South African waters for anti-submarine warfare was negligible to say the least. By 8 October, the RN South Atlantic Command in Simons Town had only four destroyers and one corvette available to hunt the German submarines, and by 10 October, a Free French corvette, Commandant Detroyat, and two more British destroyers arrived which bolstered these forces. The size of the operational area off Cape Town, and by taking into account the fact that the submarine attacks extended towards Durban, created a situation unfavourable to the effective employment of anti-submarine vessels. ${ }^{62}$ Third, by October 1942, there was very little air cover available over the South African coast and of that, most of the SAAF crews were untrained on their machines and in the general aspects of anti-submarine warfare. ${ }^{63}$ Last, only a limited number of group sailings (hereafter referred to as 'convoys') were in operation along the west coast of South Africa for ships travelling along the Cape Town-Freetown shipping route. The majority of the merchants sunk during the first U-boat campaign in South African waters travelled independently in an area 30 to 300 miles offshore, making their protection from submarine attack an immensely difficult task. ${ }^{64}$

By the end of March 1943, anti-submarine warfare in South African waters had become so efficient that the Operation Seehund boats only managed to sink a small number of Allied merchant shipping. The declining numbers of merchant shipping sunk off the South African coast by March 1943, and essentially for the remainder of the war, can be explained through a number of antisubmarine matters that were put in place after Operation Eisbär. ${ }^{65}$ The UDF and the RN South Atlantic Command underwent a process through which lessons were learned owing to the U-boat attacks off the South African coast, and measures were hence implemented and improved to prevent the same situation from occurring again. It is thus safe to surmise that Operation Eisbär served as the nadir of anti-submarine warfare in South Africa. ${ }^{66}$

In terms of anti-submarine warfare in South African waters, the following measures were implemented after Operation Eisbär, which can explain the decrease in the number of merchant sunk in these waters.$^{67}$ First, most of the slow-moving merchant shipping off the coast of South Africa was formed into convoys whilst travelling between the ports of Cape Town and Durban. Merchant shipping travelling eastwards towards Cape Town was formed into convoys upon reaching Walvis Bay, and subsequently travelled in this formation to the Cape and other South African ports. Merchant shipping approaching South African waters through the Mozambican Channel were formed into convoys at Lourenço Marques in Mozambique, after which the convoys proceeded towards Durban under escort. These measures were implemented during 1942. On 16 September 1943, the use of 
convoys was temporarily ceased, only to be reinstated on 26 March 1944 after the resurgence of submarine attacks. Special shipping, such as troopships, however, received as much air cover as could be provided by the SAAF and RAF squadrons along the South African coast, and RN vessels also accompanied them to ensure that U-boats refrained from trying to attack them. ${ }^{68}$ Second, by March 1943, a greater number of RN vessels were available to the South Atlantic Command to use as defensive screens to convoys operating along the South African coast. Their minuscule numbers, however, meant that only token protection could be offered to the convoys, for seven corvettes and 21 trawlers had to protect an average of 38 convoys which operated in South African waters per month. ${ }^{69}$ Third, dedicated merchant shipping routes around the South African coastline were instituted, which were close enough to the shore in order to allow for adequate air cover to be provided by the SAAF and RAF squadrons. This move ensured that near continuous air cover existed over a convoy whilst travelling along the South African coastline. ${ }^{70}$ Fourth, the formation of a Combined Operations Room in Cape Town, manned by members of the UDF and RN South Atlantic Command, meant that unity of action was ensured whilst planning offensive operations against U-boats known to be operational in the South African waters. The experience gained by both the South African and Allied air and naval forces during Operation Eisbär, ensured that swift, calculated, decisions were taken for the remainder of the war in order to the hunt the German submarines still operational off the South African coast. ${ }^{71}$ Through the aid of direction-finding stations along the South African coast, and intelligence obtained from Government Communications Headquarters (GCHQ) in the United Kingdom through wireless intercepts, the presence of U-boats in South African waters was fixed, and appropriate action could thus be taken. ${ }^{72}$ Last, shortly after the commencement of Operation Eisbär, the UDF established a Port Security Force. The aim of the Port Security Force was to ensure the safety and security of all South African commercial harbours, and to prevent sabotage and subversive activities from occurring. ${ }^{73}$

There were, however, certain salient points that remained troublesome in terms of antisubmarine measures that were implemented around the South African coastline, and these contributed to a certain extent to some of the merchant vessels lost in said waters. ${ }^{74}$ First, the quality and experience of convoy commanders available in South Africa remained wanting throughout the war, as service with the South Atlantic Command might still have been regarded as a backwater posting to the cream of the RN officers. An experienced convoy commander, with adequate anti-submarine vessels and staff under his command, proved crucial when under attack by U-boats. ${ }^{75}$ Second, some coastal lights, such as the Cape Agulhas lighthouse whose lights had not been completely dimmed, aided the U-boats in identifying targets. The sinking of the merchant, the Queen Anne, was the result of the ship being silhouetted by the light of the Cape Agulhas lighthouse, prior to U-509 sinking it. By midFebruary 1943, however, all coastal lights had been reduced in power and illumination. ${ }^{76}$ Third, during some stages, the SAAF and RAF aircraft, which provided cover for the convoys travelled too far away from it, and during one such incident, the Colombia was sunk without any aircraft taking offensive action against the U-boat. As such, a revised close escort programme had been instituted for aircraft accompanying convoys, whereby circuits of 20,10 and 5 miles had to be maintained by the aircraft. This allowed for close air support to the convoy, whilst some of the aircraft conducted longrange reconnaissance ahead and to the flanks of the convoy. ${ }^{77}$ Fourth, despite the improvements in shore-ship wireless transmissions, and the greater number of wireless stations/transmitters available along the South African coast by the latter half of 1943, the communications between merchant and shore-based establishments remained wanting, and thus news of U-boat attacks was often received too late to respond to them. ${ }^{78}$ Fifth, the convoy escorts, especially the South African trawlers, were too slow to conduct efficient anti-submarine sweeps around the convoys, and thus their speed was a considerable risk to the protection of the convoys around the South African coast. ${ }^{79}$ Last, considerable trouble was experienced with the leakage of shipping information from within the ranks of the UDF 
and other naval and foreign troops in South Africa. The censorship, and in turn leakage, of shipping information had been deemed such a threat that it was even suggested that a war measure be introduced to safeguard information that was deemed as useful to the Axis agents regarding merchant shipping around the South African coast. ${ }^{80}$

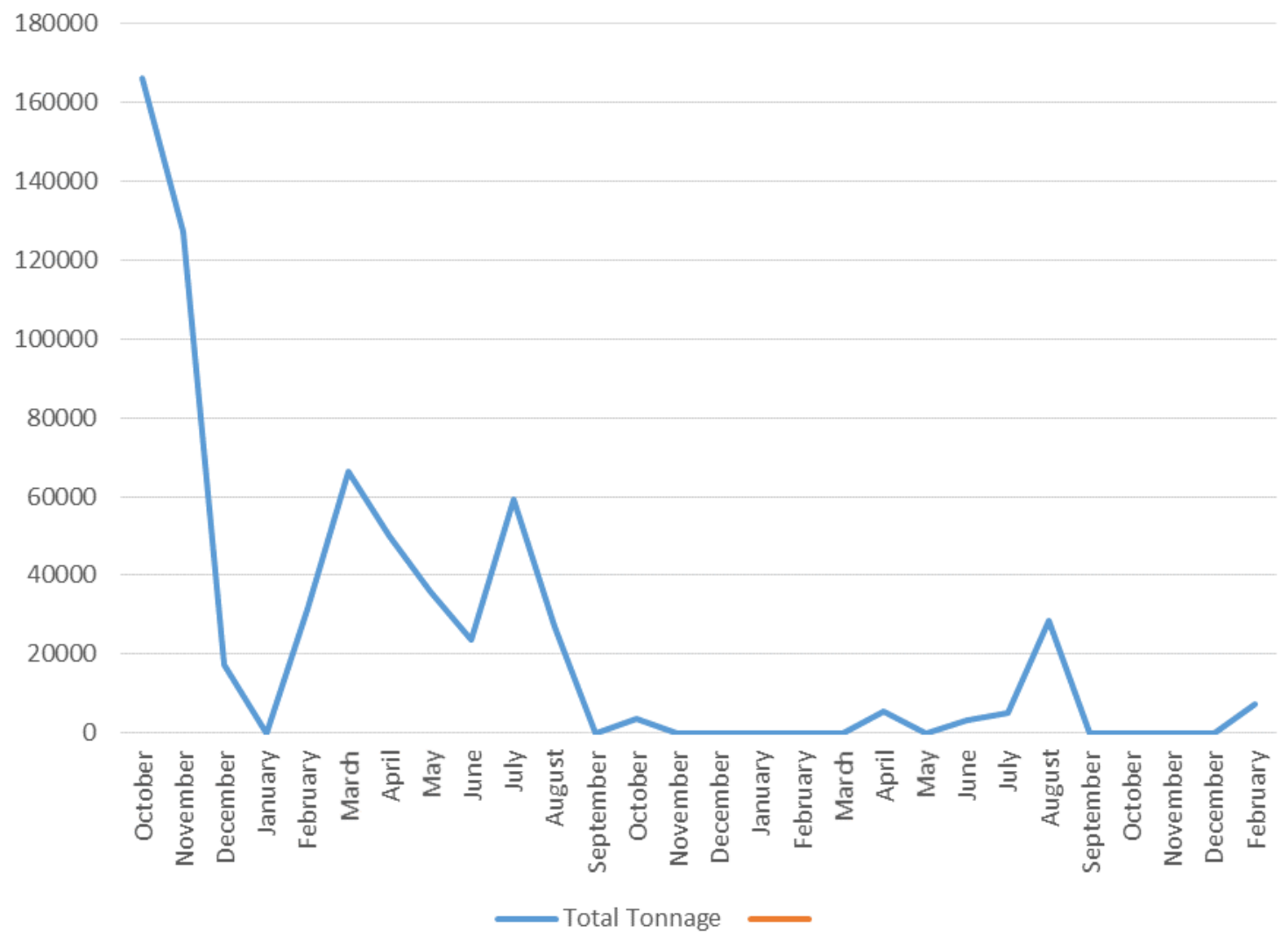

Graph 3: Gross merchant tonnage lost to U-boat action in South African waters, 1942-1945

The best measure of the effectiveness of the anti-submarine measures off the coast of South Africa, apart from the diminishing merchant losses, was in fact the three German submarines which were sunk during 1942 (U-179), 1943 (U-197) and 1944 (UIT-22). One can thus argue that the Uboats were sunk at the beginning, at the height, and at the end of the U-boat offensives in South African waters, which furthermore reflects positively on the improvements which were made in antisubmarine warfare throughout the period concerned, and the success in disallowing the U-boats to have the initiative in this area ${ }^{82}$ On 8 October 1942, the RN destroyers Nizam, Foxhound and Active, which were deployed 60 miles to the west of Dassen Island, in order to protect the approaches to the Cape Town harbour, managed to sink $U-179$ (Sobe) after a successful attack with depth charges. ${ }^{83}$ On 19 August 1943, signals, which had been sent between the BdU, U-181, U-197 and U-196, had been picked up by Combined Headquarters in South Africa. Through the wireless interception, and through direction finding, the position of $U-197$ was estimated in an operational area of approximately 250 miles south-west from Cape St Marie in Madagascar. Operating at the limits of their operational endurance, Catalinas from No. 259 RAF Squadron in St Lucia were ordered to join the search for the U-boat. The aircraft rebased to Tulear, in south-western Madagascar, which they subsequently used as 
a forward operating base during the operation. On 20 August, Catalina C/259 flown by Flight Lieutenant (Flt Lt) O Barnett, sighted U-197 approximately 300 miles south-west of Cape St Marie, and immediately attacked. Barnett succeeded in dropping six depth-charges on the U-boat, which after the attack, had a severe list to port and was leaking diesel oil. The stricken U-boat, unable to submerge, continued to be circled by Barnett's aircraft during the entire afternoon. Later in the afternoon, two further aircraft arrived on the scene and U-197 was attacked with machine guns and a further six depth-charges. The final depth charge attack managed to sink $U-197 .{ }^{84}$

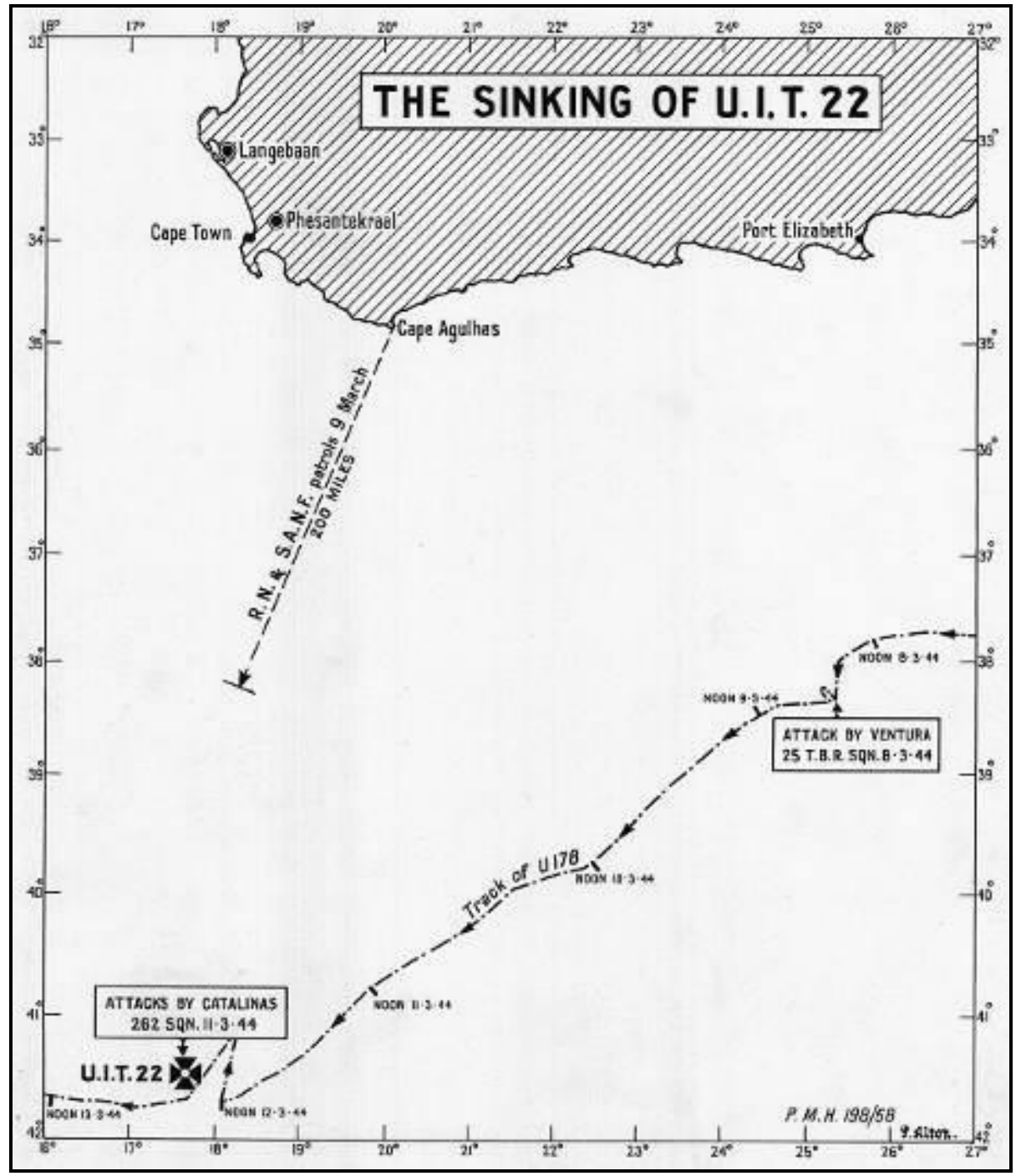

Map 3: Operation Wicketkeeper - The sinking of UIT-22 ${ }^{85}$

After June 1943, the South African waters had once more become peaceful and were practically devoid of any German submarine activity, after most troop convoys and shipping had been redirected by August 1943 to the travel through the Mediterranean. This in turn meant that merchant ships were once more permitted to travel independently, whilst the coastal SAAF and RAF squadrons had severely reduced the number of anti-submarine patrols off the South African coast. ${ }^{86}$ The situation, however, soon changed, for $U-178$ (Sphar) had been forced to return to Europe from Penang, and was ordered to use up her remaining torpedoes on the voyage home across the Indian Ocean. The German submarine, UIT-22 (Wunderlich), was ordered to rendezvous with $U-178$ in the proximity of Cape 
Town in order to be refuelled, due to UIT-22 being attacked on her journey through the South Atlantic. On 5 March 1944, the South Atlantic Station had effected such a good fix on $U-178$, through indiscriminate radio communications, that an immediate operation was ordered to attempt to destroy the U-boat. ${ }^{87}$ Operation Wicketkeeper, a combined operation between the naval, air and ground forces, was launched on 8 March 1944 with the sole intention of locating and then sinking $U-178$ who, it believed, would affect the rendezvous in an area 140 miles south-southwest from Cape Agulhas. On 8 March, U-178 was depth charged by Venturas from No. 25 SAAF Squadron, approximately 350 miles south of Port Elizabeth after which it continued its journey towards the rendezvous submerged. ${ }^{88}$

On the morning of 11 March 1944, a Catalina from No. 262 RAF Squadron, flown by Flt Lt FT Roddick, spotted UIT-22 600 miles to the south of Cape Point. Roddick initiated an attack on Wunderlich's submarine, and was met with an immediate salvo of anti-aircraft fire from the U-boat. Wunderlich had made no attempt to dive, which enabled Roddick to commence an attack with his depth charges. Roddick managed to score direct hits on the submarine with his guns, whilst the five depth charges, which he dropped, exploded in close proximity of the U-boat. The depth charges caused considerable damage to Wunderlich's submarine and it immediately began to list heavily, after which the submarine submerged leaving a large patch of oil on the surface. The U-boat resurfaced a brief while later, but was once more forced to submerge after being strafed accurately by Roddick's Catalina. Two more Catalinas joined the attack, and upon surfacing, the U-boat was attacked by these two aircraft simultaneously. The fate of UIT-22 was sealed, and upon a final attack with machine guns and depth charges, the submarine went down with all hands on 11 March $1944 .{ }^{89}$

From mid-1943 onwards, a series of combined operations, such as Wicketkeeper, were launched in order to engage German submarines known to be active off the South African coast. Operation Wicketkeeper, and its subsequent success, was thus the culmination of anti-submarine operations off the coast of South Africa, for after March 1944, only nine merchants were lost in these waters until the end of the Second World War. ${ }^{90}$ By mid-1944, the Admiralty was indeed so pleased with the success of the anti-submarine measures off the coast of South Africa that they stated, in a message to Tait, "...this is the second consecutive operation in which a U-boat passing through your area has been successfully located and probably destroyed... [and] reflects [on] the high standard of operational control". ${ }^{91}$

\section{Conclusion}

The commencement of Operation Eisbär during October 1942 signalled both the height and the gradual decline of the effectiveness of the German U-boats throughout the Second World War. The diversionary attacks ordered by the BdU off the coast of North African and Mozambique by mid1942, had indeed created the strategic effect hoped for by the BdU, before the all-out commencement of U-boat operations in South African waters during October 1942. Once the Eisbär offensive had started, the strategic initiative, however, shifted from the Germans to the Allied forces in South Africa. The South African and Allied response to the German submarine offensives was both swift and calculated, and culminated in a series of combined operations aimed at the complete destruction of U-boats operational within South African waters. Once the South African counter-measures had been activated after October 1942, a gradual decline in merchant sinkings by U-boats was evident. At the height of the German submarine offensive in 1942, 53 ships were sunk off the coast of South Africa. By September 1943, the BdU ceased to consider the waters off Cape Town as a viable operational area for U-boats, and an immense decline in the number of merchant sinkings was observed. By February 1945, the last merchant was lost to German submarine action off the coast of 
South Africa. Owing to negligible sinking results, and the loss of a number of U-boats, the BdU ordered the German submarines to various other operational areas. The waters off the South African coast might have seemed a good operational prospect to the BdU during 1942, because of the vast amount of shipping which rounded the Cape of Good Hope, but by the latter half of 1943, the South African and Allied anti-submarine measures had convinced them otherwise. For a brief while, however, the German U-boats managed to throw shipping off the coast of South Africa into disarray.

1 For the purpose of this article, South African waters extend to a position approximately $1600 \mathrm{~km}$ off the coast of South Africa, as used by LCF Turner, HR Gordon-Cumming and J Betzler in War in the southern oceans 1939-1945. Cape Town: Oxford University Press, 1961. This area was indeed the country's maritime sphere of influence during the Second World War, and all sinkings mentioned in this paper, except the Laconia, occurred within this predefined area.

2 J Keegan. Battle at sea: From man-of-war to submarine. London: Pilmico, 1988, 223-224.

3 H Busch. U-Boats at War. London: Putnam, 1955, 17-20; Keegan op. cit., pp. 224-226.

4 Keegan op. cit., pp. 221, 226-227. The London Submarine Agreement was an Anglo-German Naval treaty signed in 1936, which governed the use of submarines in times of war. For a further explanation of the London Submarine Agreement of 1936, see RH Stevens. Admiral Doenitz memoirs: Ten years and twenty days. London: Weidenfeld and Nicolson, 1959.

5 Busch op. cit., pp. 62-63.

6 VE Tarrant. The U-boat offensive 1914-1945. London: Arms and Armour Press, 1989, 100-101; Keegan op. cit., pp. 225-228.

7 An anti-submarine device that could locate and pinpoint the position of a submerged submarine at a distance of about 2500 to 3000 yards by means of echo returned from a transmitted sound beam. For further reading, see R Whinney. The U-boat peril: An anti-submarine commander's war. London: Arrow Books, 1989, 5859 and Keegan op. cit., p. 226.

8 Tarrant op. cit., 100-101.

9 Keegan op. cit., 229-230.

10 Also known as U-tankers, these boats were used to replenish wolf packs while operational. The U-tankers carried spare parts, a doctor, technicians, food stores, ammunition and extra fuel oil, which it used to replenish U-boats upon instruction from the BdU. See Busch op. cit., pp. 144-145; LCF Turner et al. op. cit., p. 158; Whinney op. cit., p. 105.

11 Stevens op. cit., p. 176. This specific book is a translation of Zehn Jahre und Zwanzig Tage. Bonn: Athenäum-Verlag Junker und Dünnhaupt, 1958.

12 The B-Dienst was the cryptographic section of the Naval High Command, which helped to monitor Allied radio traffic and hence tried to decipher these messages. See Stevens op. cit., p. 242.

13 Stevens op. cit., pp. 213-214.

14 Busch op. cit., pp. 146-147; Stevens op. cit., p. 238; AT Mahan. Naval strategy: Compared and contrasted with the principles and practise of military operations on land. London: Sampson Low, Marston \& Company, 1911, 132-133.

15 DOD Archives, Map Collection, War in the southern oceans maps.

16 Department of Defence Documentation Centre (DOD Archives), Union War Histories (UWH) Civil, Box 341, File - U-Boat matters. Questions and answers submitted by UWH section to Fregattenkapitän Gunter Hessler re U-boat warfare in South African waters.

17 Stevens op. cit., pp. 276-283; Mahan op. cit., p. 255.

18 A Wessels. "South Africa and the war against Japan 1941-1945". Military History Journal 10/3. June 1996. <http://samilitaryhistory.org/vol103aw.html> Accessed on 29 April 2014.

19 DOD Archives, Diverse, Group 1, Box 126, File - Coastal appreciations general. A Japanese attack on South Africa: An appreciation from the enemy point of view, 29 September 1942; DOD Archives, Diverse, Group 1, Box 126, File - Coastal appreciations general. Most secret communication between DECHIEF and OPPOSITELY regarding the scales of attack by sea and air in South African waters, 8 April 1943.

20 DOD Archives, Diverse, Group 1, Box 126, File - Coastal appreciations general. A Japanese attack on South Africa: An appreciation from the enemy point of view, 29 September 1942; DOD Archives, Chief of the General Staff (CGS) War, Box 122, File - Raiders. Secret report on possible operation of Italian submarines in the Indian Ocean, 3 July 1940.

21 Wessels op. cit.

22 DOD Archives, Diverse, Group 1, Box 126, File - Coastal appreciations general. A Japanese attack on South Africa: An appreciation from the enemy point of view, 29 September 1942; DOD Archives, Diverse, 
Group 1, Box 126 File - Coastal appreciations general. Most secret communication between DECHIEF and OPPOSITELY regarding the scales of attack by sea and air in South African waters, 8 April 1943.

23 Wessels op. cit.; DOD Archives, CGS War, Box 122, File - Raiders. Secret report on possible operation of Italian submarines in the Indian Ocean, 3 July 1940.

24 DOD Archives, CGS War, Box 122, File - Raiders. Secret report on possible operation of Italian submarines in the Indian Ocean, 3 July 1940; DOD Archives, Diverse, Group 1, Box 123, File - Operations surrender of enemy. Copy of message to COMIC Durban from C-in-C SA, September 1943.

25 Maritime Warfare Command. The SKL acted as the High Command of the Kriegsmarine throughout the Second World War.

26 Stevens op. cit., p. 238; Wessels op. cit., pp. 116-117.

27 Turner et al. op. cit., pp. 116-117; DOD Archives, UWH Civil, Box 340, File - Long naval history. Ships lost or damaged by enemy action in South African waters; DOD Archives, CGS War, Box 122, File Raiders. Secret report on possible operation of Italian submarines in the Indian Ocean, 3 July 1940; DOD Archives, Diverse, Group 1, Box 126, File - Coastal appreciations general. A Japanese attack on South Africa: An appreciation from the enemy point of view, 29 September 1942; Wessels op. cit.

28 DOD Archives, Diverse, Group 1, Box 127, File - Coastal area organisation. Correspondence between headquarters coastal area and Trigonometrical Survey Office Mowbray re maps, 13 August 1942.

29 HR Gordon-Cumming. "Degaussing, mine disposal and naval fixed defences". Militaria 22/1. 1992. 20-26; DOD Archives, Diverse, Group 1, Box 127, File - Defence development general (policy and general correspondence). Most secret memorandum of the War Cabinet Ad Hoc Sub-Committee on Defence Arrangements for the Indian Ocean Area, 23 February 1942.

30 DOD Archives, Diverse, Group 1, Box 126, File - Coastal appreciations general. UDF coastal command appreciation of enemy action, 11 August 1943; DOD Archives, Diverse, Group 1, Box 127, File - Defence development general (policy and general correspondence). CGS Most secret South African operations Policy, 13 April 1942.

31 DOD Archives, CGS War, Box 38, File - Blackouts and lighthouses. Correspondence between Tait to Van Ryneveld re coastal blackouts, 19 June 1942; DOD Archives, CGS War, Box 38, File - Blackouts and lighthouses. Circular from Office of the C-in-C South Atlantic Station (Tait) to Naval Liaison Officers at Durban, East London, Port Elizabeth and Cape Town re harbour and coast lights, 19 June 1942.

32 For more on the Laconia incident, see Whinney op. cit., pp. 105-111.

33 DOD Archives, Diverse, Group 1, Box 127, File - Appreciations navy. C-in-C South Atlantic appreciation of the naval situation in the Cape area, 4 October 1942.

34 DOD Archives, UWH Civil, Box 341, File - U-boat matters. Questions and answers submitted by UWH section to Fregattenkapitän Gunter Hessler re U-boat warfare in South African waters; DOD Archives, UWH Civil, Box 341, File - U-boat matters. Operation Order "Eisbär", 1 August 1942; DOD Archives, UWH Civil, Box 341, File - U-boat matters. Report on experience gained by U-459 refuelling 15 U-boats, 21 March - 15 May 1942; DOD Archives, UWH Civil, Box 341, File - U-boat material. Report on U-boat policy \& ops in South African waters by Walter Meyer.

35 DOD Archives, UWH Civil, Box 341, File - U-boat material. Report on U-boat policy \& ops in South African waters by Walter Meyer; DOD Archives, Union War Histories (UWH) Civil, Box 341, File - U-boat matters. Questions and answers submitted by UWH section to Fregattenkapitän Gunter Hessler re U-boat warfare in South African waters

36 DOD Archives, UWH Civil, Box 341, File - U-boat material. Report on U-boat policy \& ops in South African waters by Walter Meyer; DOD Archives, UWH Civil, Box 341, File - U-boat matters. Operation Order "Eisbär", 1 August 1942; DOD Archives, UWH Civil, Box 341, File - U-boat material. Emmermann (U-172) on Operation Eisbär, 17 October 1953; DOD Archives, UWH Civil, Box 341, File - U-boat material. Comments on war diary U 159 (Helmut Witte).

37 DOD Archives, UWH Civil, Box 341, File - U-boat matters. Questions and answers submitted by UWH section to Fregattenkapitän Gunter Hessler re U-boat warfare in South African waters; DOD Archives, UWH Civil, Box 341, File - U-boat material. Report on U-boat policy \& ops in South African waters by Walter Meyer.

38 This secret rendezvous area in the southern Atlantic was known as Andalusien. There were a further two secret rendezvous areas in the north Atlantic and Indian Oceans, known as Bayern and Sibirien respectively.

39 DOD Archives, UWH Civil, Box 341, File - U-boat material. Comments on war diary U 159 (Helmut Witte); DOD Archives, UWH Civil, Box 341, File - U-boat material. Report on U-boat policy \& ops in South African waters by Walter Meyer; DOD Archives, UWH Civil, Box 341, File - U-boat material. Report on my experiences on board U-68 on voyage to Cape Town from middle of August to middle of December 1942 by Walter Meyer. 
40 DOD Archives, UWH Civil, Box 341, File - U-boat material. Report on my experiences on board U-68 on voyage to Cape Town from middle of August to middle of December 1942 by Walter Meyer; DOD Archives, UWH Civil, Box 341, File - U-boat matters. Extract from war diary U-68 (Merten), 22 September - 7 October 1942; DOD Archives, UWH Civil, Box 341, File - U-boat matters. Report on experience gained by U-459 refuelling 15 U-boats, 21 March - 15 May 1942.

41 DOD Archives, UWH Civil, Box 341, File - U-boat matters. Extract from war diary U-68 (Merten), 22 September - 7 October 1942; DOD Archives, UWH Civil, Box 341, File - U-boat material. Emmermann (U-172) on Operation Eisbär, 17 October 1953; DOD Archives, UWH Civil, Box 341, File - U-boat material. Report on U-boat policy \& ops in South African waters by Walter Meyer; DOD Archives, Diverse, Group 1, Box 123, File - Operations reports Cape Fortress. Cape Fortress operations report for period 7-14 October 1942.

42 DOD Archives, UWH Civil, Box 341, File - U-boat material. Extracts from war diary U-159 (Helmut Witte), 24 August 1942 - 5 January 1943; DOD Archives, UWH Civil, Box 341, File - U-boat material. Comments on war diary U 159 (Helmut Witte); DOD Archives, UWH Civil, Box 341, File - U-boat material. Report on my experiences on board U-68 on voyage to Cape Town from middle of August to middle of December 1942 by Walter Meyer.

43 DOD Archives, UWH Civil, Box 341, File - U-boat matters. Questions and answers submitted by UWH section to Fregattenkapitän Gunter Hessler re U-boat warfare in South African waters; DOD Archives, Commander Seaward Defences (CSD), Box 33, File - Coastal area intelligence summary. Coastal area headquarters intelligence summary no. 12, 10 October 1942; DOD Archives, Diverse, Group 1, Box 123, File - Operations reports Cape Fortress. Cape Fortress operations report for period 7-14 October 1942.

44 DOD Archives, Map Collection, War in the southern oceans maps.

45 DOD Archives, Diverse, Group 1, Box 123, File - Operations reports Cape Fortress. Cape Fortress operations report for period 7-14 October 1942; DOD Archives, UWH Civil, Box 341, File - U-boat material. Report on my experiences on board U-68 on voyage to Cape Town from middle of August to middle of December 1942 by Walter Meyer.

46 DOD Archives, UWH Civil, Box 341, File - U-boat matters. Questions and answers submitted by UWH section to Fregattenkapitän Gunter Hessler re U-boat warfare in South African waters; DOD Archives, CGS War, Box 122, File - Raiders. Most secret telegram between COASTCOM and DECHIEF, 12 October 1942; DOD Archives, UWH Civil, Box 340, File - Long naval history. Ships lost or damaged by enemy action in South African waters.

47 DOD Archives, UWH Civil, Box 341, File - U-boat material. Report on U-boat policy \& ops in South African waters by Walter Meyer; DOD Archives, CGS War, Box 122, File - Raiders. Most secret communication between coastal command and CGS re dispositions of U-boats, 21 November 1942.

48 DOD Archives, UWH Civil, Box 341, File - U-boat matters. Questions and answers submitted by UWH section to Fregattenkapitän Gunter Hessler re U-boat warfare in South African waters; DOD Archives, UWH Civil, Box 340, File - Long naval history. Ships lost or damaged by enemy action in South African waters.

49 DOD Archives, UWH Civil, Box 341, File - U-boat material. Report on U-boat policy \& ops in South African waters by Walter Meyer; DOD Archives, CGS War, Box 126, File - Shipping of supplies to and from SA. Memorandum: South African shipping position, November 1942.

50 DOD Archives, UWH Civil, Box 341, File - U-boat matters. Questions and answers submitted by UWH section to Fregattenkapitän Gunter Hessler re U-boat warfare in South African waters; DOD Archives, UWH Civil, Box 341, File - U-boat matters. Report on experience gained by U-459 refuelling 15 U-boats, 21 March - 15 May 1942.

51 DOD Archives, UWH Civil, Box 341, File - U-boat material. Report on U-boat policy \& ops in South African waters by Walter Meyer; DOD Archives, UWH Civil, Box 340, File - Long naval history. Ships lost or damaged by enemy action in South African waters.

52 DOD Archives, UWH Civil, Box 341, File - U-boat matters. Questions and answers submitted by UWH section to Fregattenkapitän Gunter Hessler re U-boat warfare in South African waters; DOD Archives, UWH Civil, Box 340, File - Long naval history. Ships lost or damaged by enemy action in South African waters.

53 DOD Archives, UWH Civil, Box 341, File - U-boat material. Report on U-boat policy \& ops in South African waters by Walter Meyer; DOD Archives, UWH Civil, Box 340, File - Long naval history. Ships lost or damaged by enemy action in South African waters. The information contained within these documents was collated and reworked by the author.

54 DOD Archives, UWH Civil, Box 341, File - U-boat material. Report on U-boat policy \& ops in South African waters by Walter Meyer; DOD Archives, UWH Civil, Box 340, File - Long naval history. Ships lost or damaged by enemy action in South African waters. 
55 DOD Archives, UWH Civil, Box 341, File - U-boat matters. Questions and answers submitted by UWH section to Fregattenkapitän Gunter Hessler re U-boat warfare in South African waters; DOD Archives, UWH Civil, Box 340, File - Long naval history. Ships lost or damaged by enemy action in South African waters.

56 DOD Archives, UWH Civil, Box 340, File - Long naval history. Ships lost or damaged by enemy action in South African waters; Tarrant op. cit., pp. 148-151. The information contained within these documents was collated and reworked by the author.

57 DOD Archives, UWH Civil, Box 341, File - U-boat material. Operationsbefehl "Monsun", 10 June 1943; DOD Archives, CGS War, Box 263, File - Sitreps coastal area. Top secret signals 1944-1945 re movement of U-boats.

58 DOD Archives, UWH Civil, Box 341, File - U-boat matters. Questions and answers submitted by UWH section to Fregattenkapitän Gunter Hessler re U-boat warfare in South African waters; DOD Archives, UWH Civil, Box 341, File - U-boat material. Report on U-boat policy \& ops in South African waters by Walter Meyer; DOD Archives, UWH Civil, Box 340, File - Long naval history. Ships lost or damaged by enemy action in South African waters; DOD Archives, CGS War, Box 265, File - Sitreps coastal area. Sitrep from Coastcom (War Room) to Dechief \& Fortcom C.T. DBN., P.E., 4 March 1945.

59 HR Gordon-Cumming. Official history of the South African Naval Forces during the Second World War (1939-1945). Simon's Town: Naval Heritage Society of South Africa, 2008, 79-83; DOD Archives, UWH Civil, Box 341, File - U-boat material. Report on U-boat policy \& ops in South African waters by Walter Meyer; DOD Archives, UWH Civil, Box 340, File - Long naval history. Ships lost or damaged by enemy action in South African waters; Tarrant op. cit., pp. 148-151.

60 DOD Archives, UWH Civil, Box 339, File - Gordon Cumming U-boat material. The Commander-in-Chief South Atlantic and eastern fleet, Report on the safety of shipping in South African water, 30 March 1943; DOD Archives, Diverse, Group 1, Box 126, File - Coastal appreciations general. UDF Coastal Command appreciation of enemy action, 11 August 1943.

61 DOD Archives, Commander Fortress Air Defence (CFAD), Box 12, File - Attacks on U-boats and submarines. Lecture on A/S warfare by Wing Commander Lombard, 22 February 1943; DOD Archives, CFAD, Box 12, File - Attacks on U-boats and submarines. Circular from CCAD to Fortress Command and SAAF squadrons regarding U-boat attacks, 12 January 1943; DOD Archives, CSD, Box 33, File - Coastal area intelligence summary. Coastal area headquarters intelligence summary No. 12, 10 October 1942.

62 DOD Archives, CGS War, Box 122, File - Raiders. Cape Area naval intelligence pamphlet (13 October 1942) re U-boat activities off Cape of Good Hope October 1942; DOD Archives, CGS War, Box 122, File Raiders. Telegram from C-in-C South Atlantic to High Commissioner for the United Kingdom in South Africa re submarine attacks off Cape Town, 11 October 1942; DOD Archives, CGS War, Box 122, File Raiders and DOD archives, Diverse, Group 1, Box 123, File - Operations reports Cape Fortress. Cape Fortress operations report for period 7-14 October 1942.

63 DOD Archives, Diverse, Group 1, Box 123, File - Operations reports Cape Fortress. Cape Fortress operations report for Period 7-14 October 1942.

64 DOD Archives, UWH Civil, Box 339, File - Gordon Cumming U-boat material. The Commander-in-Chief South Atlantic and eastern fleet, Report on the safety of shipping in South African water, 30 March 1943; DOD Archives, UWH Civil, Box 339, File - Correspondence with Admiralty Historical Section (Raiders, Sinkings etc.). Notes on submarine offensive round the Cape which began in October 1942.

65 DOD Archives, Diverse, Group 1, Box 123, File - Operations reports Cape Fortress. Cape Fortress operations report for period 7-14 October 1942; DOD Archives, UWH Civil, Box 339, File - Gordon Cumming U-boat material. The Commander-in-Chief South Atlantic and eastern fleet, Report on the safety of shipping in South African water, 30 March 1943.

66 DOD Archives, Diverse, Group 1, Box 123, File - Operations reports Cape Fortress. Cape Fortress operations report for period 7-14 October 1942.

67 DOD Archives, Diverse, Group 1, Box 126, File - Coastal appreciations general. UDF Coastal Command appreciation of enemy action, 11 August 1943; DOD Archives, Diverse, Group 1, Box 123, File Operations reports Cape Fortress. Cape Fortress operations report for period 7-14 October 1942.

68 DOD Archives, CSD, Box 15, File - Group sailing operations Union waters. Note on commencement and ceasing of group sailings, 1944; DOD Archives, CSD, Box 15, File - Policy (escort groups). Note on commencement and ceasing of group sailings, 1944; DOD Archives, CSD, Box 43, File - SANF Antisubmarine Warfare Committees. Minutes of A/S Sub-Committee meeting coastal area headquarters, 12 March 1943; DOD Archives, CSD, Box 25, File - SANF Escort Force exercises. Proposed Atlantic convoy instructions re action to counter U-boats anti-asdic tactics.

69 DOD Archives, CSD, Box 15, File - Policy (escort groups). CSD Approval of exchange with RN of A/S vessels, 15 November 1943; DOD Archives, CSD, Box 15, File - Policy (escort groups). Personal 
correspondence between CSD and GOC coastal area re SANF vessels and A/S warfare, 30 October 1942; DOD Archives, CSD, Box 15, File - Policy (escort groups). Correspondence between CSD and SANOi/c Durban re SANF A/S vessels on escort duties, 28 April 1943; DOD Archives, CSD, Box 15, File - Policy (escort groups). Correspondence between CSD and SANOi/c Durban re participation of SANF vessels in convoy escorts from SA ports, 23 January 1943; DOD Archives, Diverse, Group 1, Box 126, File Operation "Throttle". Operation Throttle ops order, 30 May 1944; DOD Archives, Diverse, Group 1, Box 126, File - Operation "Steadfast". Operation Steadfast ops order, 12 June 1944; DOD Archives, Diverse, Group 1, Box 125, File - Woodcutter. Operation Woodcutter ops order, 1 January 1944.

70 DOD Archives, CSD, Box 43, File - SANF Anti-submarine Warfare Committees. Minutes of A/S SubCommittee meeting coastal area headquarters, 12 March 1943; DOD Archives, CSD, Box 43, File - SANF Anti-submarine Warfare Committees. Report by Officer Commanding HMSAS Gannet re U-boat warfare in the South Atlantic, 10 June 1943; DOD Archives, CSD, Box 25, File - SANF Escort Force exercises. Proposed Atlantic convoy instructions re action to counter U-boats anti-asdic tactics.

71 DOD Archives, CSD, Box 33, File - SA Naval Forces operational intelligence reports. Operational intelligence report no. 15 re inshore operations by U-boats, 19 July 1944; DOD Archives, UWH Civil, Box 339, File - Gordon Cumming U-boat material. The Commander-in-Chief South Atlantic and eastern fleet, Report on the safety of shipping in South African water, 30 March 1943; DOD Archives, Diverse, Group 1, Box 123, File - Operations reports Cape Fortress. Cape Fortress operations report for period 7-14 October 1942; DOD Archives, CSD, Box 43, File - SANF Anti-submarine Warfare Committees. Minutes of A/S SubCommittee meeting coastal area headquarters, 12 March 1943; DOD Archives, Diverse, Group 1, Box 125, File - Operation instruction coastal area (serial). Coastal area ops instr no. 28, 23 March 1944; DOD Archives, Diverse, Group 1, Box 123, File - Coast 22 (O) Organisation general. Letter from air headquarters East Africa to OC Advanced Operations Section air headquarters East Africa re operation control to be exercised by the Advanced Operations Section, air headquarters, East Africa, situated at Cape Town, 11 May 1943.

72 DOD Archives, CGS War, Box 265, File sitreps coastal area. Most secret cypher between Coastcom and Dechief Fortcoms, 21 August 1943; DOD Archives, CGS War, Box 229, File - Cypher section general. Confidential letter from CGS Office to SGO re cipher and coding staff DHQ, 23 October 1939; DOD Archives, CGS War, Box 228, File - UDE stations. GHQ top secret memo to DCS re UDE stations, 28 September 1944; DOD Archives, CGS War, Box 228, File - Signals facilities for RAFTC \& BOAC. CGS circular re tele-facilities SA aircraft and BOAC before war and now (dominion circular despatch G.14: 22 March 1944 - 16 May 1944).

73 DOD Archives, CGS War, Box 38, File - Port and docks security measures. Secret notes of meeting held at Defence headquarters in connection with the proposed formation of a Port Security Unit, 15 October 1942.

74 DOD Archives, UWH Civil, Box 339, File - Gordon Cumming U-boat material. The Commander-in-Chief South Atlantic and eastern fleet, Report on the safety of shipping in South African water, 30 March 1943; DOD Archives, Diverse, Group 1, Box 123, File - Operations reports Cape Fortress. Cape Fortress operations report for period 7-14 October 1942.

75 DOD Archives, UWH Civil, Box 339, File - Gordon Cumming U-boat material. The Commander-in-Chief South Atlantic and eastern fleet, Report on the safety of shipping in South African water, 30 March 1943.

76 DOD Archives, CGS War, Box 38, File - Blackouts and lighthouses. Correspondence between Secretary of Defence and Minister of Justice re black-out conditions coastal area, 29 September 1943; DOD Archives, UWH Civil, Box 341, File - U-boat material. Report on U-boat policy \& ops in South African waters by Walter Meyer; DOD Archives, Diverse, Group 1, Box 125, Operation instruction coastal area (serial). Coastal area ops instr no. 30, 3 May 1944.

77 DOD Archives, CFAD, Box 12, File - Intelligence Cape Fortress summary. Cape Fortress intelligence summary no. 10, 4 December 1942 (Appendix A - Anti-submarine warfare).

78 DOD Archives, CGS War, Box 226, File - W.T. stations: Ship to shore \& ship to aircraft. Letter from British High Commissioner to South Africa (Harlech) to Smuts re Admiralty Policy with regard to wireless communication, 9 March 1943.

79 DOD Archives, CSD, Box 25, File - SANF Escort Force exercises. Proposed Atlantic convoy instructions re action to counter U-boats anti-asdic tactics; DOD Archives, UWH Civil, Box 339, File - Gordon Cumming U-boat material. The Commander-in-Chief South Atlantic and eastern fleet, Report on the safety of shipping in South African water, 30 March 1943; DOD Archives, CGS War, Box226, File - Wireless stations (communications with). Secret note on the interception of illicit communications, 2 November 1939.

80 DOD Archives, CGS War, Box 124, File - Security of ship movements. CGS letter to Secretary for External Affairs re leakage of information regarding shipping, 12 January 1944; DOD Archives, CGS War, Box 124, File - Security of ship movements. Memo to CGS Office from DDMI re leakage of shipping information, 7 January 1944. 
81 DOD Archives, UWH Civil, Box 341, File - U-boat material. Report on U-boat policy \& ops in South African waters by Walter Meyer; DOD Archives, UWH Civil, Box 340, File - Long naval history. Ships lost or damaged by enemy action in South African waters. The information contained within these documents was collated and reworked by the author.

82 DOD Archives, CSD, Box 33, File - SA Naval Forces operational intelligence reports. Operational intelligence report no. 15 re inshore operations by U-boats, 19 July 1944; DOD Archives, UWH Civil, Box 339, File - Gordon Cumming U-boat material. The Commander-in-Chief South Atlantic and eastern fleet, Report on the safety of shipping in South African water, 30 March 1943; DOD Archives, CSD, Box 43, File - SANF Anti-submarine Warfare Committees. Report by Officer Commanding HMSAS Gannet re U-boat warfare in the South Atlantic, 10 June 1943.

83 DOD Archives, CGS War, Box 122, File - Raiders. Most secret cable between DECHIEF and COASTCOM re sinking of German submarine off Cape Town, 9 October 1942; Turner et al. op. cit., pp. 177-178.

84 Turner et al. op. cit., pp. 234-235.

85 DOD Archives, Map collection, War in the southern oceans maps.

86 DOD Archives, Diverse, Group 1, Box 127, File - Defence development general (Policy and General Correspondence). Most secret signal between DECHIEF and COASTCOM re shipping around Cape, 5 August 1943.

87 DOD Archives, Diverse, Group 1, Box 125, File - Operation Wicketkeeper. Messages and sitreps concerning Operation Wicketkeeper March 1944; DOD Archives, Diverse, Group 1, Box 125, File Operation Wicketkeeper. Operation Wicketkeeper, 8 March 1944; DOD Archives, CGS War, Box 265, File - Sitreps coastal area. Most secret Sitrep from Dechief Cape Town to Coastcom, 7 March 1944; Turner et al. op. cit., pp. 242-243.

88 DOD Archives, Diverse, Group 1, Box 125, File - Operation Wicketkeeper. Operation Wicketkeeper, 8 March 1944; DOD Archives, SAAF war diaries, Box 125, File - A3 (25 Sqdn Jul '43 - Mar '44). 25 Squadron SAAF war diary March 1944; DOD Archives, SAAF war diaries, Box 125, File - A3 (25 Sqdn Jul '43 - Mar '44). 25 Squadron SAAF war diary March 1944, Secret UBAT report (Appendix B); Turner et al. op. cit., pp. 242-243.

89 DOD Archives, SAAF war diaries, Box 124, File - A4 (23 Sqdn Jan-Dec 1944). 23 Squadron SAAF war diary March 1944; DOD Archives, SAAF war diaries, Box 127, File - D2 (262 Squadron Sept 42 - May 44). 262 Squadron RAF war diary March 1944; DOD Archives, SAAF war diaries, Box 127, File - D2 (262 Squadron Sept 42 - May 44). 262 Squadron RAF war diary March 1944, Secret UBAT report - Flt Lt Roddick (Appendix); DOD Archives, SAAF war diaries, Box 182, File - A1 (SAAF war diary CCAD). CCAD coastal area headquarters war diary March 1944; DOD Archives, SAAF war diaries, Box 122, File - A4 (22 Sqdn Jan - May 1944). 22 Squadron SAAF war diary March 1944; Turner et al. op. cit., pp. 243244.

90 DOD Archives, Diverse, Group 1, Box 126, File - Operation "Throttle". Operation Throttle ops order, 30 May 1944; DOD Archives, Diverse, Group 1, Box 126, File - Operation "Steadfast". Operation Steadfast ops order, 12 June 1944; DOD Archives, Diverse, Group 1, Box 125, File - Woodcutter. Operation Woodcutter ops order, 1 January 1944; DOD Archives, Diverse, Group 1, Box 126, File - Operation Tricolour (location + destruction U-boat). Message from Admiralty to C-in-C SA re Operation Tricolour, 25 July 1944; DOD Archives, Diverse, Group 1, Box 123, File - Operation "Vehement". Operation Vehement ops order, 4 August 1944; DOD Archives, Diverse, Group 1, Box 125, File - Barrage II. Operation Bustard ops order, 27 November 1943.

91 DOD Archives, Diverse, Group 1, Box 126, File - Operation Tricolour (location + destruction U-boat). Message from Admiralty to C-in-C SA re Operation Tricolour, 25 July 1944. 